\title{
Peningkatan Produksi Pengrajin Batu Bata Melalui Perbaikan Proses Pencetakan
}

\author{
Abdul Kadir Muhammad ${ }^{1, \mathrm{a}}$ Muhammad Arsyad $^{1, \mathrm{~b}}$ dan A.M.Anzarih ${ }^{1, \mathrm{c}}$ \\ ${ }^{1}$ Teknik Mesin Politeknik Negeri Ujung Pandang, J1. Perintis Kemerdekaaan KM.10, Makassar, 90245, Indonesia. \\ ${ }^{a}$ kadir.muhammad@poliupg.ac.id \\ b arsyadhabe@poliupg.ac.id \\ c anzarih@poliupg.ac.id
}

\begin{abstract}
The purpose of this study is to improve the production process of brick craftsmen. Brick production process consists of four stages: printing, drying, burning, and cooling. Of the four stages, which will be completed in this research is the process of printing bricks. The printing process still uses simple equipment that is a rectangular wooden beam with a size of 20 cm $x 10 \mathrm{~cm} \times 5 \mathrm{~cm}$. The printing process includes: preparation of raw materials by hoeing the soil, making the dough by trampling to the shape of a paste, printing using a printing tool. For this method, for 4 people craftsmen can print bricks as much as 2,000 pieces / day ( 8 hours work / day). The number of bricks is ideal for once combustion of $\mathbf{4 0 , 0 0 0}$ pieces. For reach that amount it takes 20 days. The method applied in improving the production process of brick craftsmen is the application of brick machine. The operation of the brick printing machine requires 4 persons with their respective functions: 1 person to insert the soil into the printing machine, 1 person to cut the brick bar, 1 person to move the bricks from the printing machine, 1 person to bring the bricks to the drying place. Based on the result of the test, it is concluded that by using the brick machine, the dough making is easier and shorter, the production capacity increased to 6,780 bricks / day, the time required for the production of 40,000 pieces of bricks is 6 days.
\end{abstract}

Keywords - bricks, productivity, printing machines, dough

Abstrak-Tujuan penelitian ini ialah untuk memperbaiki proses produksi pengrajin batu bata. Proses produksi batu bata terdiri dari empat tahapan yaitu: pencetakan, pengeringan, pembakaran, dan pendinginan. Dari keempat tahapan tersebut, yang akan diselesaikan dalam penelitian ini yaitu proses pencetakan batu bata. Proses pencetakan masih manggunakan peralatan sederhana yaitu balok kayu berbentuk empat persegi panjang dengan ukuran $20 \mathrm{~cm} \times 10 \mathrm{~cm} \quad x \quad 5 \quad \mathrm{~cm}$. Proses pencetakan meliputi: penyiapan bahan baku dengan cara mencangkul tanah, pembuatan adonan dengan cara menginjakinjak hingga berbentuk pasta, pencetakan dengan menggunakan alat cetak. Dengan motede tersebut, untuk 4 orang pengrajin mampu mencetak batu-bata sebanyak 2.000 buah/hari $(8 \mathrm{jam}$ kerja/hari). Jumlah batu bata yang ideal untuk sekali pembakaran yaitu 40.000 buah. Untuk mencapai jumlah tersebut maka dibutuhkan waktu 20 hari. Metode yang diterapkan dalam memperbaiki proses produksi pengrajin batu bata yaitu penerapan mesin pencetak batu bata. Untuk mencapai tujuan tersebut maka penelitian ini dibagi menjadi beberapa tahap yaitu perancangan, pembuatan komponen-komponen, perakitan komponen-komponen, pengujian dan perbaikan. Penggunaan allat tersebut membutuhkan 4 orang dengan fungsi masingmasing: 1 orang untuk memasukkan tanah ke dalam mesin pencetak, 1 orang untuk memotong batu bata batangan, 1 orang untuk memindahkan batu bata dari mesin pencetak, 1 orang untuk membawa batu-bata ke tempat pengeringan. Berdasarkan dengan hasil pengujian yang dilakukan disimpulkan bahwa dengan menggunakan mesin pencetak batu bata tersebut maka pembuatan adonan lebih mudah dan lebih singkat, kapasitas produksi meningkat menjadi 6.780 buah batu bata/hari, waktu yang dibutuhkan untuk produksi batu bata 40.000 buah yaitu 6 hari.

Kata Kunci : batu bata, produktivitas, mesin pencetak, adonan.

\section{Pendahuluan}

Batu bata merupakan salah satu komponen bahan bangunan yang vital. Seiring dengan pesatnya pembangunan infra struktur seperti ruko, hotel, rumah tinggal, dan bangunan lainnya mengakibatkan jumlah batu bata yang dibutuhkan meningkat pula. Oleh karena itu, pengrajin batu bata dituntut untuk meningkatkan pula kapasitas produksinya. Untuk memenuhi hal tersebut, maka pengrajin tidak dapat lagi mempertahankan cara-cara tradisional yang digunakan selama ini melainkan sudah waktunya ditunjang oleh tekonologi. Pembuatan batu bata terdiri dari beberapa proses yaitu persiapan bahan baku, pembuatan adonan, pencetakan, pengeringan, pembakaran, dan pendinginan.

Dalam industri batu bata terdiri dari 3 kelompok kepentingan yaitu (1) pemilik lahan, (2) pengrajin, dan (buruh). Pemilik lahan ialah orang yang mempunyai hak milik atas lahan yang diolah, Pengrajin ialah orang yang 
mengusahakan pembuatan batu bata, sedangkan Buruh ialah orang yang dipekerjakan oleh Pengrajin. Umumnya pengrajin batu bata menggunakan buruh minimal 2 orang dengan kapasitas produksi maksimal 1000 buah/orang dengan jam kerja 8 jam/hari. Alat produksi yang digunakan untuk mencetak masih menggunakan alat tradisional sebagaimana pada Gambar 1 [1]. Untuk melakukan pembakaran yang efektif tiap pembakaran, maka jumlah batu bata yang dibakar ialah 40.000 buah. Jumlah tersebut memerlukan waktu kurang lebih 70 s.d 85 hari pada kondisi cuaca yang cerah dengan rincian: (a) waktu pencetakan 45 s.d 60 hari, (b) waktu pengeringan selama 5 hari, (c) waktu pembakaran selama 10 hari, (d) waktu pendinginan siap jual selama 5 hari. Bahan bakar yang digunakan yaitu sekam padi yang tersedia melimpah di Kabupaten Sidrap, dan abu hasil pembakaran sekam padi tersebut digunakan juga sebagai pelapis batu bata bahkan sebagai media pencampur adonan [2].



Gambar 1. Alat Tardisional Pencetak Batu Bata

Berdasarkan hasil pengamatan dan wawancara tim peneliti dengan beberapa pengrajin batu bata di Kabupaten Sidrap, permasalahan pokok yang sering dihadapi pengrajin ialah persoalan tenaga kerja/buruh. Buruh yang digunakana umumnya: (a) berasal dari daerah luar bahkan dari kabupaten lain, (b) selalu minta upah duluan dengan besaran minimal Rp 5.000.000, (c) sering meninggalkan tempat dengan berbagai alasan tanpa penyampaian bahkan biasa tidak kembali lagi. Buruh hanya mau bekerja kalau diberi upah terlebih dahulu sebesar Rp 5.000.000. Hal ini berarti buruh telah menerima upahnya untuk dua bulan setengah, disisi lain buruh sering meninggalkan tempat tanpa sepengetahuan pengrajin. Permasalahan lain yang dihadapi ialah masih rendahnya efisiensi hasil pembakaran yaitu $82,5 \%$. Jadi, hanya 33.000 dari 40.000 buah batu bata yang layak jual, berarti ada 7000 buah batu bata yang tidak bisa dijual karena tidak terbakar secara sempurna. Hal ini terjadi karena proses pembakaran batu bata dilakukan secara tradisional, yaitu batu bata disusun sedemikian rupa pada daerah (ladang) terbuka yang bagian atasnya diberi atap sebagai pelindung terhadap air hujan [2][3]. Mesin pencetak batu bata telah dikembangkan antara lain di Universitas Merdeka (1994 -1999) dengan kemampuan produksi 1000 batu bata/jam untuk 5 tenaga kerja [4].

\section{Metode Penelitian}

Metode penanganan masalah dilakukan dengan cara memperbaiki peralatan prosess pencetakan. Perbaikan proses pencetakan dilakukan dengan cara merubah dari cara tradisional ke cara mekanis. Hal ini dilakukan dengan tahapan: perancangan, pembuatan, dan uji coba. Mesin pencetak batu bata tersebut terdiri dari 3 bagian yaitu motor penggerak, pembuat adonan dan batu bata batangan, dan pemotong batu bata batangan menjadi batu bata. Perancangan dan pembuatan mesin tersebut akan memperhatikan kekurangan yang dimiliki mesin sebelumnya sebagaimana yang diperlihatkan pada Gambar 2 [3]. Mesin pencetak batu bata ini menggunakan mesin penggerak diesel. Cara kerja mesin pencetak ini yaitu pengrajin memasukkan tanah liat (bahan baku) ke dalam mesin pencetak batu bata (corong pemasukan) kemudian mesin menghasilkan batu bata yang berbentuk batangan yang selanjutnya begitu batubata batangan keluar melalui corong pengeluaran langsung dipotong secara manual sesuai dengan ukuran batu bata.

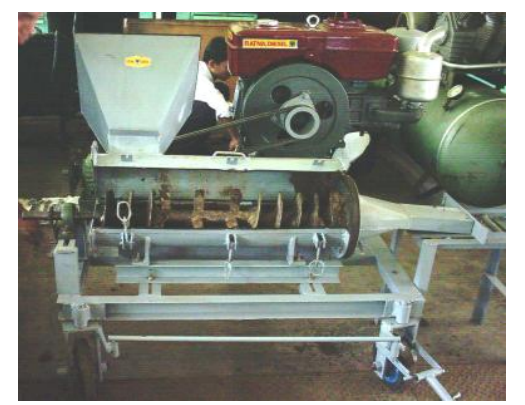

Gambar 2. Mesin Pencetak Batu Bata

\section{Hasil dan Pembahasan}

Hasil yang diperoleh dari penelitian ini yaitu sebuah mesin pencetak batu bata yang terdiri dari tiga bagian utama yaitu: mesin penggerak, mesin pembuat adonan 
dan pencetak batu bata batangan, dan alat pemotong batu bata sebagaimana Gambar 3 .

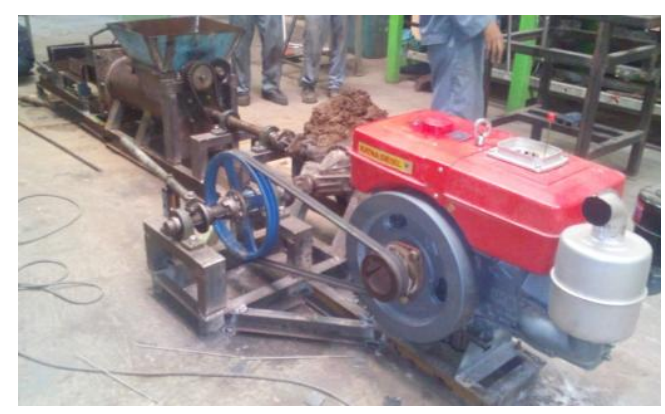

Gambar 3. Mesin Pencetak Batu bata

Pengoperasian mesin pencetak batu bata tersebut membutuhkan 4 orang yaitu : 1 orang bertugas memasukkan tanah ke dalam corong pemasukan, 1 orang bertugas memotong batu bata batangan yang keluar dari corong pengeluaran, 1 orang bertugas memindahkan batu bata dari tempat cetakan, dan 1 orang bertugas mengangkat batu bata ke lokasi pengeringan.

Bahan baku diolah dalam suatu silinder yang berisi poros spiral. Poros spiral tersebut, selain membuat adonan juga berfungsi untuk menekan tanah menuju corong pengeluaran. Batu bata yang keluar dari corong pengeluaran masih berbentuk batu bata batangan, kemudian dipotong dengan menggunakan media pemotong yang terbuat dari kawat, dan sekali memotong menghasilkan 5 buah batu bata seperti yang diperlihatkan pada Gambar 4. Dengan demikian, proses pembuatan adonan menjadi lebih mudah dibandingan dengan cara tradisional yang masih digunakan oleh pengrajin batu bata.



Gambar 4. Proses Pemotongan Batu Bata Batangan

Tabel 1. menunjukkan waktu yang dibutuhkan untuk membuat adonan dan mencetak batu bata serta kapasitas produksi. Proses pembuatan adonan yaitu sejak tanah dimasukkan melalui corong pemasukan hingga keluar melalui corong pengeluaran dalam bentuk batu batangan dan siap dipotong, dimana proses ini membutuhkan waktu 55 detik. Kemudian untuk mencetak batu bata sebanyak 5 buah membutuhkan waktu yang bervariasi dari 8 hingga 14 detik.
Hal ini dipengaruhi oleh kecepatan memasukkan tanah ke dalam corong pemasukan. Namun, kelelalahan tenaga kerja juga harus diperhatikan.

Tabel 1. Hasil Pengujian Mesin Pencetak Batu Bata

\begin{tabular}{|c|c|c|c|}
\hline Waktu (s) & Jumlah (buah) & $\begin{array}{c}\text { Kualitas Batu } \\
\text { Bata }\end{array}$ & Keterangan \\
\hline 55 & \multicolumn{2}{|c|}{ Pembuatan adonan } & 1'56-2'51 \\
\hline 11 & 5 & Baik & $2^{\prime} 51-3^{\prime} 02$ \\
\hline 12 & 5 & Baik & 3’02-3'14 \\
\hline 14 & 5 & Baik & 3'14-3'28 \\
\hline 9 & 5 & Baik & 3’28-3’37 \\
\hline 8 & 5 & Baik & 3'37-3’45 \\
\hline 11 & 5 & Baik & 3’45-3’56 \\
\hline 14 & 5 & Baik & $3^{\prime} 56-4^{\prime} 10$ \\
\hline 14 & 5 & Baik & $4^{\prime} 10-4{ }^{\prime} 24$ \\
\hline 148 & 40 & Baik & $1^{\prime} 56-2 ' 51$ \\
\hline
\end{tabular}

Berdasarkan Tabel 1 tersebut, waktu yang dibutuhkan untuk menghasilkan 40 buah batu bata yaitu sebanyak 148 detik, termasuk waktu yang dibutuhkan membuat adonan. Oleh karena itu, dapat dikatakan bahwa produktivitas mesin pencetak batu bata ini dalam 1 menit yaitu 16 buah batu bata atau sebanyak 970 buah dalam satu jam. Hasil ini hampir sama dengan produksi alat yang dihasilkan oleh Sujatmiko [4], begitu juga oleh Setiawaty [5][6]. Bila waktu ratarata kerja efektif pengrajin/tenaga kerja 7 jam tiap hari maka kapasitas produksinya menjadi 6.780 buah. Akan tetapi masih rendah bila dibandingan dengan Razak [7].

Tabel 2. Perbandingan Metode Lama (Tradisional) dengan Metode Baru (Mesin Pencetak)

\begin{tabular}{|c|c|c|}
\hline \multirow{2}{*}{ Variabel } & \multicolumn{2}{|c|}{ Metode Pencetakan Batu Bata } \\
\cline { 2 - 3 } & Tardisional & Mesin Pencetak \\
\hline Waktu & 8 jam & 8 jam \\
\hline Tenaga Kerja & 4 orang & 4 orang \\
\hline Produksi & 2.000 buah & 6.780 buah \\
\hline $\begin{array}{c}\text { Waktu untuk } \\
40.000 \text { buah }\end{array}$ & 20 hari & 6 hari \\
\hline
\end{tabular}

Tabel 2 memperlihatkan perbandingan kapasitas produksi mesin pencetak dengan alat tradisional pencetak dengan variabel yang sama yaitu waktu kerja dan jumlah tenaga kerja. Dengan kapasitas produksi 6.780 buah batu bata tiap hari, maka hanya membutuhkan waktu 6 hari untuk memproduksi batu bata sebanyak 40.000 buah. Hal ini menunjukkan bahwa proses pembakaran dapat dilakukan lebih cepat. 


\section{Kesimpulan}

Sebagaimana telah dijelaskan pada bab sebelumnya, maka disimpulkan bahwa :

1. Proses Pembuatan Adonan menjadi mudah dan singkat.

2. Kapasitas produksi meningkat dari $2.000 \mathrm{buah} / \mathrm{hari}$, 6.780 buah/hari.

3. Waktu produksi untuk 40.000 buah, menurun dari 20 hari menjadi 6 hari.

\section{Ucapan Terima Kasih}

Kegiatan penelitian ini terlaksana atas bantuan dana dari DRPM Dikti, maupun bantuan berupa izin penggunaan segala fasilitas bengkel dan laboratorium yang ada di lingkungan PNUP. Oleh karena itu, kami tak lupa mengucapkan terima kasih yang tak terhingga.

\section{Daftar Pustaka}

[1] Arsyad, M., Firman. Anzarih, A.M. 2007. Optimalisasi Pendapatan Pengrajin Batu Bata Melalui Penerapan Mesin Pencetak Batu Bata dan Tungku Hemat Energi. Laporan Hibah Kompetitif. Makassar: UPPM Politeknik Negeri Ujung Pandang.

[2] Arsyad, M. Susanto, T.A. Arman. 2013. I $I_{b}$ Kelompok Usaha Batu Bata Di Kabupaten Sidrap Sulawesi Selatan. Laporan Pelaksanaan IbM. Makassar: UPPM Politeknik Negeri Ujung Pandang.

[3] Arsyad, M., Arman. Susanto, T.A. 2014. Analisa Penerapan Mesin Pencetak Batu Bata Pada Sentra Industri Batu Bata. Teknik Industri. 20(1):1-8.

[4] Sujatmiko.1999. Mesin Pencetak Batu Batu Dengan Prinsip Kerja Mesin Getuk Lindri : MAJALAH GAMMA: edisi 2 Mei 1999. Jakarta: PT. Garda Media Mandiri.

[5] Setiawaty, Tetty. Alat Cetak Batu Bata Sistem Getar dan Tekan. http://www.dikti.org/p3m/03007s.html

[6] Rauf, Bakhriani. Pencetakan Batu Merah Sistem Hammer Gravitasi. http://www.dikti.org/p3m/03008s.html

[7] Razak, .R.A.1999.Industri Keramik. Jakarta: Balai Pustaka. 